\title{
A Comparison of Rural and Urban Tourism Experiences: A South African Example
}

\author{
Felix Amoah*, Laetitia Radder, Marlé van Eyk \\ Department of Marketing Management, Nelson Mandela University, South Africa \\ *Felix.Amoah@mandela.ac.za, Laetitia.Radder@mandela.ac.za, marle.vaneyk@mandela.ac.za
}

\begin{abstract}
Tourism is a rewarding sector for several countries as it presents opportunities for growth and development. While tourism attractions are predominantly located in either a rural or an urban destination, literature lacks comparative research about experiences in these two contexts. The purpose of this study was to compare tourists' experiences of visiting a rural or an urban destination in South Africa. Data were conveniently obtained from 401 tourists who visited either one of two rural, or one of two selected urban tourist destinations. This study found significant differences in tourist perceptions for escape and peace of mind. Tourists felt more strongly/positive that they were escaping when visiting a rural tourism destination than when visiting an urban tourism destination. However, the study also revealed that tourists felt more secure and safe and that their privacy was prioritised (peace of mind) at an urban tourism destination than at a rural tourism destination. Tourism destination managers and governments may use the findings of the study to improve the tourist experience and promote a competitive platform for the tourism destination to attract more tourists.
\end{abstract}

Keywords: Escape, Peace of mind, Rural, Tourist experience, Urban

\section{Introduction}

Tourism has become a lucrative and fast-growing economic sector in several countries. Globally, the tourism industry has experienced a steady growth on a yearly basis (UNWTO, 2017). Current developments show that the number of international tourist arrivals globally increased by $4.6 \%$ (from 2014 to 2015), which generated export earnings of US\$1.5 trillion (United Nations World Tourism Organisation [UNWTO], 2017). Sectors such as accommodation, transportation, entertainment and attractions obtained approximately 2.3 trillion dollars in proceeds in 2016 (Statista, 2017). In Africa, the role and impact of tourism cannot be underestimated. Between the years 1994 and 2014, international tourist arrivals to Africa grew by an average of $6 \%$ annually, creating an export revenue of $9 \%$ per year (United Nations Conference on Trade and Development [UNCTD], 2017). The average total contribution to the gross domestic product (GDP) increased from US\$69 billion between 1995 and 1998 to US $\$ 166$ billion between 2011 and 2014 (a growth from 6.8\% to $8.5 \%$ of the GDP in Africa) (UNCTD, 2017). In the employment sector, tourism generated more than 21 million jobs on average between 2011 and2014, which translates into $7.1 \%$ of all jobs in Africa (UNCTD, 2017). The above indicators demonstrate the contributions of the tourism sector to the African continent. In South Africa, tourism also plays a major role in the economy. In 2013, 14.3 million international travellers visited the country, an increase from 13.1 million in 2012 and 12.1 million in 2011 (Statistics South Africa [Stats SA], 2017). This injected a GDP value of R103.6 billion into the economy, an increase from R93.5 billion in 2012 (Stats SA, 2017). Domestic visitors contributed 57\% (R124.7 billion) of the total tourism revenue in 2013, while international visitors contributed 43\% (R94.2 billion) (Stats SA, 2017). The total spent by tourists in 2013 was R218.9 billion, an increase of $9.7 \%$ from R199.4 billion in 2012 (Stats SA, 2017).

South Africa's tourism sector boasts of vast and attractive tourism destinations predominantly located in rural (e.g. Hole in the Wall, Sugarloaf Rock, and Isinuka Springs) and urban (e.g. Table Mountain, Cape Point, Robben Island, and Addo Elephant National Park) areas of the country. A rural tourism destination which is sometimes referred to as a nature-based destination (Loureiro, 2014) capitalises on natural and cultural attractions such as community-based tourism, eco-tourism, cultural tourism, adventure tourism, guest farms, backpacking, horse-riding and agri-tourism (Viljeon \& Tlabela, 2007). Rural tourism destinations also promote empowerment opportunities for local people through capacity building and the acquisition of positions (e.g. managerial responsibility) (Butler, 2017). Challenges associated with rural tourism destinations include poor accessibility and lack of infrastructure (e.g. good roads and access to the Internet), non-availability of skills, lack of interest of investors, and low-quality products (Viljoen \& Tlabela, 2007). These challenges may be a disadvantage when compared to urban tourism destinations. 
Holland, Burian and Dixey (2003) argue that it is important to develop tourism in rural areas to increase the participation of the poor in the development of tourism and bring wider benefits to rural areas such as contributing to poverty reduction through employment creation. Tourism managers in rural areas, therefore, have to find ways of effectively competing with urban areas. One such way could be to examine tourists' perceptions of their experiences in rural and urban destinations. While several aspects of the tourism sector in South Africa have been examined (Ferreira \& Hunter, 2017; George, 2017; Rogerson, 2015), a comparison between tourists' experiences of visiting a rural or an urban tourism destination has received limited attention despite Kirillova, Fu, Lehto and Cai's (2014) recommendation that a systematic comparison of nature-based (rural) and urban destinations would be fertile ground for future research. Thus, the purpose of the current study is to help fill this void. The study is of importance in two different folds. Firstly, the findings will assist destination managers to identify areas for improving tourists' experiences such as the physical environment, entertainment, education activities, safety, security and privacy issues. Secondly, the findings will assist the tourism sector in the Eastern Cape of South Africa to remain competitive and attract more tourists. The remaining sections of this paper are categorised in the following manner. Firstly, in the literature review, a distinction is made between rural and urban tourism destinations, followed by a review on the tourism experience, its dimensions, and the application thereof within both a rural and urban context. Next, the research methodology employed is discussed, whereafter, the results are presented. The next section concludes, discusses, and highlights the implications of the findings. The final section mentions the limitations and makes recommendations for future research.

\section{Literature Review}

Rural and urban tourism destinations: From a tourism perspective, a destination can be described as "...places that facilitate the conditions of a tourism experience which includes services and activities (e.g. lodging and attractions) that can contribute to the overall experience of the visited area. It offers a combination of tangible and intangible clues and creates the spatial experience context for the tourist" (Cetin \& Bilgihan, 2016:140). Loureiro (2014:6) describes rural tourism as a "...market niche in the countryside, which involves lodgings with a small number of beds and a set of possible activities such as appreciating landscapes, eating and drinking regional food and wine, visiting regional fairs, or learning how to make handicrafts". A city, on the other hand, is an existing urban area which offers various social and cultural experiences to customers (Carlisle et al., 2016). Urban tourism destinations provide avenues for major regional tourism activities and for attracting day trip visitors (Carlisle et al., 2016). Rural tourism destinations in South Africa, such as Port Saint Johns are characterised by unsung treasure troves which comprised of the beautiful natural landscape, art galleries, nature reserves, beaches and other forms of attractions. However, as in the case of other rural tourism destinations, access to telecommunication facilities such as telephone and internet is a challenge, roads remain in poor condition, and the closest airport offers limited and expensive flights. On the contrary, urban tourism destinations in South Africa have good infrastructure (e.g. roads, water, electricity, telephone) and other exciting places (e.g. sports stadia/events, cinemas, nightclubs, casinos, beaches, shopping malls).

Tourism experience: There is no precise definition of the term 'experience' as experiences are holistic, personal and situational (Kalbach, 2016) and could be positive or negative. Authors define the concept of experiences from different perspectives. For example, Sundbo and Darmer (2008) define an experience as a mental journey that leaves the customer with memories of having performed something special, having learned something, or having just had fun. Kalbach (2016) maintains that experiences include actions, thoughts and feelings over time, which are not objective as they result from the subjective perception of the individual, and move across the lenses of situations and circumstances. Adhikari and Bhattacharya (2016) view experience as a customer's engagement in an activity that creates expectations and results in something that can be remembered. Experiences function as a personal source of information for the stories people tell about their lives and are important for their self-perception (Mehmetoglu \& Engen, 2011). The foundation of the current paper is built on the work of Pine and Gilmore (1998), pioneers of the experience economy. According to Pine and Gilmore (1999), experiences are staged through engaging individuals and connecting with them in a personal and memorable way. These authors' ambition was to assist organisations to stage experience for customers using their market offering (goods and services) which would, in turn, allow 
organisations to fully engage with their customers and charge higher prices for those experiences (Pine \& Gilmore, 1999).

As experiences are produced in different industries such as art, tourism, information technology, entertainment, as well as manufacturing and services, the creation of experiences differs from discipline to discipline (Sundbo \& Darmer, 2008). Therefore, an organisation from a certain discipline cannot copy the experience creation from a different field. For example, a theatre company cannot replicate the experience created bya travel agency or a film company. In the context of tourism, experiences are created through a process of visiting, learning, and enjoying activities in an environment away from home (Jurowski, 2009). The advent of technological transformations and consumers becoming more sophisticated and demanding, have exerted pressure on the tourism industry to shift their focus from facilities and services to offering experiences. To meet the demand of the market, tourism destinations must now offer customised experiences and engage consumers in activities and experiences (Jurowski, 2009). Since most tourism destinations are clustered in either urban and rural areas, it is important to identify how visitors perceive a rural and urban tourism experience. When tourists visit an urban or a rural destination, their aim is not just to consume certain products or services on offer, but rather enjoy the experience they will receive from the visit. Thus, customer experience entails the personal interpretation of the service process that the visitor received (Ferreira \& Teixeira, 2013). Tourism experiences are not limited to what happens during the actual encounter at a rural or an urban destination; they start before the actual meeting through the building up of expectations and memorable experiences which also contribute to the visitor's after-the-event experience of the encounter. The engagement in a tourism experience means that visitors seldom have the same experience, even though they are experiencing the same encounter (Sundbo \& Darmer, 2008). The expectation of a pleasurable and memorable experience is what motivates visitors to decide on either a rural or an urban tourism destination. Tourism providers need to consider the provision of elements that meet the interests and expectations of the visitors. The current study set out to determine whether perceptions of such experiences differ in the case of rural and urban tourism destinations.

Dimensions of the tourism experience: Customers' growing desire for experiences have contributed to the multidimensionality of the construct (Amoah, Radder \&Van Eyk, 2016). For the current study, the four experience dimensions proposed by Pine and Gilmore (1999) (education, aesthetics, entertainment and escapism) and peace of mind (Amoah, Radder \&Van Eyk 2016) served as the basis for comparing tourists' experiences of visiting rural or urban tourism destinations. For example, when examining bed-and-breakfast guests' experiences, Oh et al. (2007) discovered that the experience dimensions (education, aesthetics, entertainment, and escape) differed regarding their relevance to all tourists. The study by Quadri-Felitti and Fiore (2012) on rural wine experiences supported the findings of Oh et al. (2007). Similar to differences in experiences found by Oh et al. (2007) and Quadri-Felitti and Fiore (2012) respectively in the accommodation and rural wine sectors, one would expect that there will be variances between rural and urban tourism experiences. These dimensions are discussed below.

Education: To truly enlighten tourists and further their knowledge or skills, educational experiences provided by organisations must engage the mind and body (Pine \& Gilmore, 1999). Educational experience includes knowledge acquired, enhanced skills, learning, and stimulating curiosity. Enhanced skills involve a series of events that happen in the presence of the tourists, or that will engage the tourists' minds and bodies (Ali, Hussain \& Ragavan, 2014; Oh, Fiore \& Jeoung, 2007). Activities such as visiting an art gallery or an exhibition may constitute an educational experience at a destination. An educational experience would increase visitors' skills and help enhance their knowledge in becoming expressive thinkers. For example, a visit to a rural or an urban destination should enhance their general knowledge about the city or a location, stimulate their curiosity to learn new things as well as improve their knowledge about different cultures. A visit to a museum would serve as a source of information and knowledge to visitors, enhance their imagination and allow them to create a mental construction based on observation and exciting information (Achiam, 2016). Opportunities afforded to tourists to acquire knowledge about the history and origin of a destination, the culture of the people, and their way of living would contribute to an educational experience. Many of these activities are available in the rural and urban destinations forming the empirical focus of the current study. Education is frequently found to be an important element of the tourism experience. For example, Loureiro (2014) found education to be the second most relevant element of the overall rural 
experience. MacDonald and Jolliffe (2003) identify that education experience enriches the tourist's satisfaction at a rural destination. This will help attract more tourist to the destination. Huang, Beeco, Hallo and Norman (2016) establish that tourists who are learning oriented are prepared to visit a rural tourism destination that has a variety of educational activities. Knowledge of such experience will assist destination managers to better the education experience offered to tourists. Therefore, it is hypothesised that:

H1: There is a significant difference between tourists' experience of the education dimension in rural and urban tourism destinations.

Aesthetics: The second experience dimension proposed in this study is aesthetics. Aesthetics is an important value-adding dimension and a critical satisfier at a destination (Kirilova et al., 2014). Quadri-Felitti and Fiore (2012) describe aesthetics as a passive appreciation of how a destination appeals to the senses. The aesthetics dimension is associated with the attractiveness or pleasantness of a destination, its unique architectural design, the scenery, a sense of harmony, attractive hotels, and the interior decoration of venues (Oh et al., 2007). In the context of rural and urban tourism destinations, tourists' experiential needs would be fulfilled provided the destination offers a sense of harmony to visitors, is suitably attractive, and provides pleasure to the senses. Factors such as the neatness of the physical surroundings, good facilities at various lodgings, a clean beach, and appealing landscapes may be necessities to achieve tourists' satisfaction. Tourism literature highlights the importance of aesthetics. According to Loureiro (2014) and Oh et al. (2007), the aesthetics dimension emerged as the most important dimension in shaping the tourists' overall experience. Although the focus of Kirillova et al. (2014) was not to compare tourists' perceptions of the aesthetics associated with nature-based (rural) and urban destinations, it emerged from their study that nature-based destinations with a clean and fresh environment with no human interference is considered beautiful. On the other hand, in urban destinations with great experiences, complex offerings of human activity, fashion, and innovative designs are viewed as beautiful because they add to the image of the urban destination (Kirillova et al., 2014). These findings provided a divergent view of how tourists perceive aesthetics at both rural and urban destinations. Therefore, it is hypothesised that:

H2: There is a significant difference between tourists' experience of the aesthetic dimension in rural and urban tourism destinations.

Entertainment: The third experience dimension relevant to this study is entertainment. Entertainment results when a customer passively absorbs the activities or performances of others (Pine \& Gilmore, 1998,1999). According to MacDonald and Jolliffe (2003), entertainment activities enhances tourists experience at a rural destination and could result in visitor satisfaction. An example of an entertainment experience would be attending special events and watching theatre performances (Ali et al., 2014) such as a show at the Opera House (in the case of an urban tourism destination) or a cultural dance or performances and songs of the local ethnic group (in the case of a rural tourism destination). A further example of entertainment might also be to include live performances of contemporary music to attract tourists to a destination. Irrespective of where the experience takes place, entertainment experiences should be captivating, enhance visitor involvement, and encourage the tourist to stay, enjoy and have fun (Pine \& Gilmore, 1999). Therefore, it is hypothesised that:

H3: There is a significant difference between tourists' experience of the entertainment dimension in rural and urban tourism destinations.

Escape: The fourth experience dimension selected for this study is that of escape. Escapism involves a satisfying experience that visitors create for themselves, and it makes them feel as if they have swapped environment or location. Escapism is also associated with visitors' feelings that they are living in a different world, time or place (Oh et al., 2007). It involves intense immersion during the observation of a performance or an occurrence (Oh et al., 2007). Tourism provides a way for people to escape from their normal lifestyle to experience something extraordinary (Oh et al., 2007). For example, both rural and urban tourists can immerse themselves in different activities such as seeing beautiful landscapes, relaxing at the beach, and enjoying different menus. Several authors (Beames, 2003; Cohen \& Ben-Nun, 2009; Quadri-Felitti \& Fiore, 2012) found that rural wine tourists want more to do than just visit the guesthouse. This implies that engaging the tourist fully in different activities will immerse the individual in the experience. A variety of activities will help the tourists realise the escapist dimension (Quadri-Felitti \& Fiore, 2012). However, it is postulated that tourist's perception of escapist activities will be unequal in rural and urban tourism 
destinations. Discovering tourists' perceptions if any, would assist destination managers to improve the experience offered and enhance their destination attractiveness.

Therefore, it is hypothesised that:

H4: There is a significant difference between tourists' experience of the escape dimension in rural and urban tourism destinations.

Peace of mind: The final experience dimension explored for the current study is that of peace of mind. This dimension includes the tourists' need for safety, security and privacy at a destination (Amoah et al., 2016). According to Barbini and Presutti (2014), peace of mind includes the physical comfort and safety, together with privacy and relaxation. Tourists' main objective for visiting a destination would not only include the physical consumption of the product or service but would also prioritise personal safety, such as less crime at a destination. High crime rates in both rural and urban destinations may serve as a hindrance to the tourism industry (George, 2017). Peace of mind would involve the visitors' assessment of all the interactions with the service provider before, during and after the purchase of a product or service (Klaus \& Maklan, 2013). Prior research has emphasised the importance of peace of mind to the tourist experience. For example, Klaus and Maklan (2013) found that peace of mind has a positive impact on customer satisfaction, loyalty and positive spreading of word-of-mouth information. In fact, peace of mind exerts the highest effect on customer satisfaction, loyalty and word-of-mouth recommendation (Klaus \& Maklan, 2013). This implies that a destination that can provide tourists with safety, security and comfort may attract more tourists. Tourist's perceptions of safety, security and privacy-related issues within the context of the current study will assist tourism destination managers and government to intensify the need to ensure that tourists are safe and secured. Therefore, it is hypothesised that:

H5: There is a significant difference between tourists' experience of the peace of mind dimension in rural and urban tourism destinations.

\section{Methodology}

Primary data for the study was obtained through self-administered structured questionnaires administered to respondents using convenience sampling. Two rural (Port St. Johns and Coffee Bay Hole in the Wall) and two urban (Port Elizabeth and East London) coastal destinations in the Eastern Cape of South Africa were selected for the study. These destinations were selected because they have similar attractions (sea/beach, lodging facilities and other exciting sites that attract tourists) and are most visited by tourists in the Eastern Cape. A total of 25 measurement items were adapted from research by Amoah et al. (2016), Loureiro (2014) and Oh et al. (2007). Academic experts in the fields of tourism and marketing at a public university in South Africa reviewed the items for face and content validity. Their extensive review resulted in 20 items being retained. A five-point Likert scale ranging from "strongly disagree" (1) to "strongly agree" (5) was used. A total of 401 respondents (200 from the urban destinations and 201 from the rural destinations) completed the final questionnaire. All the 401 completed questionnaires were used for the analyses. The Kaiser-MeyerOlkin (KMO) measure of sampling adequacy and Bartletts's test of sphericity were utilised to verify the data suitability for factor analysis. A KMO of 0.909 and a significant Bartlett's test $(\mathrm{p}=.000)$ suggest that the data set was appropriate for factor analysis (Pallant, 2013). Cronbach's alpha coefficient was employed to test the internal consistency reliability of the measurement items (Nunnally, 1978). All the Cronbaches alpha were within the minimum threshold of 0.70 (Nunnally, 1978). Finally, the t-test was used to compare tourists' experiences of rural or urban tourism destinations.

\section{Results}

Profile of respondents for both rural and urban tourism destinations: More males (56.9\%) than females (43.1\%) participated in the research. The majority of the respondents were between 18 and 30 years of age (35.2\%) and between 31 and 40 years of age (25.2\%). Many of the respondents reside in South Africa (89.8\%). Dominant among the respondents were those who had obtained a diploma or a degree (51.6\%). Regarding their income, the largest proportion of the respondents (40.4\%) earn more than R15000 per month. Table 1 contains detailed profile information of the respondents. 
Descriptive statistics associated with the measurement items: Table 2 reports on the descriptive statistics of the measured experience items. The mean scores for all the items were above 3.0, which indicates that the respondents were positive about their experience at both the rural and urban tourism destinations visited. The highest rating of $\mathrm{M}=3.87$ occurred in item 9 ( $\mathrm{I}$ had lots of fun) which measured the entertainment dimension. The lowest rating, $M=3.26$, occurred in item 19 (I felt this destination provided a sense of personal security) measuring the peace of mind dimension.

Exploratory factor analysis (EFA) for combined rural and urban tourism experience: Principal component analysis (PCA) and principal axis factoring (PAF) extraction methods were used to determine the number of factors. Five factors (see Table 3 ) were extracted and these accounted for $63.996 \%$ of the total variance in the dataset.

Table 1: Profile of respondents

\begin{tabular}{lll}
\hline & Frequency & $\mathbf{\%}$ \\
\hline Gender & 228 & 56.9 \\
$\quad$ Male & 173 & 43.1 \\
Female & & \\
Age & 141 & 35.2 \\
18-30 & 101 & 25.2 \\
$31-40$ & 70 & 17.5 \\
$41-50$ & 89 & 22.1 \\
51+ & 360 & \\
Country of residence & 41 & 89.8 \\
South Africa & & 10.2 \\
Other & 116 & \\
Education & 207 & 1.0 \\
Lower than high school & 74 & 28.9 \\
High school/certificate & & 51.6 \\
Diploma/degree & 83 & 18.5 \\
Postgraduate & 67 & 20.7 \\
Income & 89 & 16.7 \\
$\quad<$ R3000 & 162 & 22.2 \\
R3000-R8000 & & 40.4 \\
R8001-R15000 & \\
>R15000 &
\end{tabular}

Table 2: Descriptive statistics of the experience items for both rural and urban tourism experience Proposed dimensions and items

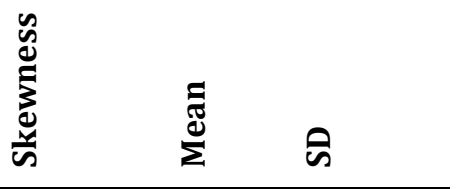

\begin{tabular}{|c|c|c|c|c|}
\hline & Education & & & \\
\hline A1 & The experience made me more knowledgeable & -0.33 & 3.53 & 0.98 \\
\hline A2 & I learnt a lot at the various tourist destinations & -0.40 & 3.55 & 0.90 \\
\hline A3 & The experience stimulated my curiosity to learn new things & -0.32 & 3.54 & 1.00 \\
\hline A4 & $\begin{array}{l}\text { The experience at this destination really enhanced my skills } \\
\text { Aesthetics }\end{array}$ & -0.25 & 3.45 & 0.99 \\
\hline A5 & The destination offered a sense of harmony & -0.37 & 3.72 & 0.97 \\
\hline A6 & The experience received was very pleasant & -0.40 & 3.75 & 0.95 \\
\hline A7 & The environment was very attractive & -0.40 & 3.72 & 1.00 \\
\hline A8 & $\begin{array}{l}\text { The environment provided pleasure to my senses } \\
\text { Entertainment }\end{array}$ & -0.38 & 3.77 & 0.95 \\
\hline A9 & I had lots of fun & -0.54 & 3.87 & 0.97 \\
\hline A10 & I enjoyed watching what others do at this tourist destination & -0.26 & 3.56 & 0.94 \\
\hline
\end{tabular}




\begin{tabular}{|c|c|c|c|c|}
\hline A11 & Watching others perform made me feel happy & -0.45 & 3.63 & 0.97 \\
\hline A12 & $\begin{array}{l}\text { Activities of others were amusing to watch } \\
\text { Escape }\end{array}$ & -0.46 & 3.52 & 1.03 \\
\hline A13 & I felt like I played a different character being at this destination & -0.45 & 3.46 & 1.09 \\
\hline A14 & $\begin{array}{l}\text { I felt like living in a different time or place when in the tourist } \\
\text { destination }\end{array}$ & -0.37 & 3.47 & 1.10 \\
\hline A15 & The experience made me feel like someone else & -0.42 & 3.30 & 1.13 \\
\hline A16 & $\begin{array}{l}\text { The experience provided a complete escape from reality } \\
\text { Peace of mind }\end{array}$ & -0.24 & 3.43 & 1.06 \\
\hline A17 & I felt physically comfortable visiting this tourist destination & -0.43 & 3.59 & 1.03 \\
\hline A18 & $\begin{array}{l}\text { I felt that my property was safe when visiting various tourist } \\
\text { attractions in the area }\end{array}$ & -0.20 & 3.28 & 1.11 \\
\hline A19 & I felt this destination provided a sense of personal security & -0.26 & 3.26 & 1.08 \\
\hline A20 & $\begin{array}{l}\text { I felt that my privacy was respected everywhere at the various } \\
\text { tourist destinations in the area }\end{array}$ & -0.22 & 3.32 & 1.09 \\
\hline
\end{tabular}

Table 3: Exploratory factor analysis (EFA)

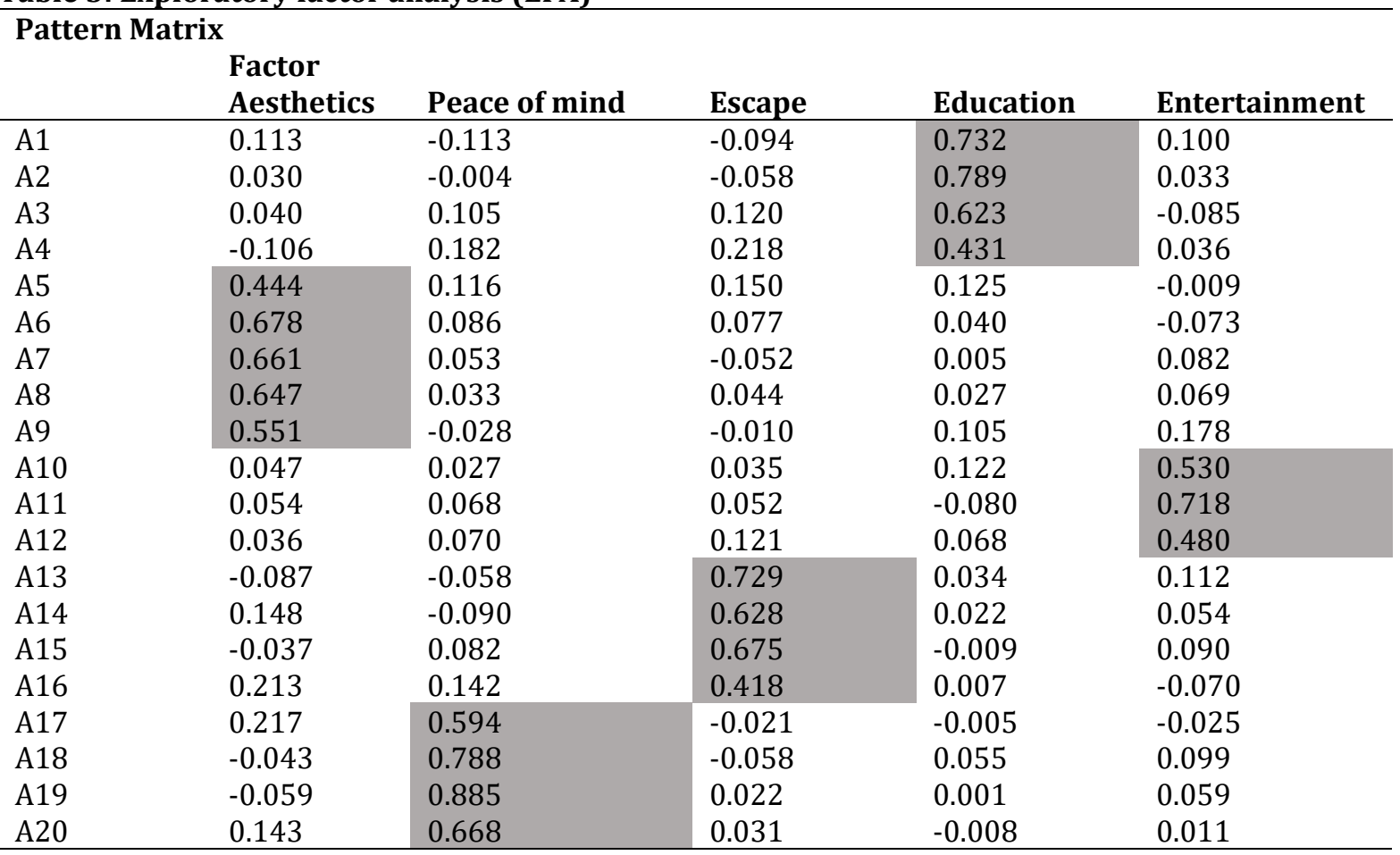

The Cronbach's alphas were examined after the EFA. All the Cronbach's alphas (Education=0.78; Aesthetics=0.82; Entertainment $=0.71$; Escape $=0.77$; Peace of mind=0.86) were within the recommended threshold of 0.70 (Andrew, Pedersen \& McEvoy, 2011; Hair, Black, Babin \& Anderson, 2010; Nunnally, 1978).

Comparison of rural and urban coastal experiences: The respondents' experiences of a rural tourism destination were compared with the experiences of visiting an urban tourism destination. The findings are displayed in Table 5. 
Table 5: Comparison of rural and urban coastal experiences

\begin{tabular}{|c|c|c|c|c|c|c|c|c|c|c|c|}
\hline & $\begin{array}{l}\text { Mean } \\
\text { Urban }\end{array}$ & $\begin{array}{l}\text { Mean } \\
\text { Rural }\end{array}$ & $\begin{array}{l}\text { t- } \\
\text { value }\end{array}$ & Df & $\mathbf{p}$ & $\begin{array}{l}\text { Valid N } \\
\text { Urban }\end{array}$ & $\begin{array}{l}\text { Valid N } \\
\text { Rural }\end{array}$ & $\begin{array}{l}\text { Std. } \\
\text { Dev. } \\
\text { Urban }\end{array}$ & $\begin{array}{l}\text { Std. } \\
\text { Dev. } \\
\text { Rural }\end{array}$ & $\begin{array}{l}\text { Cohen's } \\
\text { d }\end{array}$ & $\begin{array}{l}\text { Practical } \\
\text { signif. }\end{array}$ \\
\hline Education & 3.46 & 3.57 & -1.54 & 399 & 0.124 & 200 & 201 & 0.83 & 0.66 & & \\
\hline Aesthetics & 3.81 & 3.72 & 1.22 & 399 & 0.222 & 200 & 201 & 0.83 & 0.64 & & \\
\hline Entertainment & 3.56 & 3.59 & -0.32 & 399 & 0.745 & 200 & 201 & 0.85 & 0.71 & & \\
\hline Escape & 3.28 & 3.55 & -3.28 & 399 & 0.001 & 200 & 201 & 0.92 & 0.73 & 0.33 & Small** \\
\hline Peace of Mind & 3.51 & 3.22 & 3.26 & 399 & 0.001 & 200 & 201 & 0.85 & 0.94 & 0.33 & Small** \\
\hline
\end{tabular}

Statistically significant $\left({ }^{* *} \mathrm{p}<0.05\right)$

The findings summarised in Table 5 demonstrate that there is a significant difference between only two of the dimensions, namely escape $(p=0.001)$ and peace of mind $(p=0.001)$. However, Cohen's $d$ indicates a small effect size or practical significance in both cases.

\section{Conclusion, Discussion, Implications}

Tourism has been an emerging lucrative business across the globe in recent years. Several countries, especially in Africa, have focused their attention on attracting tourists to their countries. Proceeds from tourism in the years 2011 to 2014 contributed immensely to Africa's GDP and accelerated employment in various sectors (UNCTD, 2017). These developments generated a platform for business to compete. The rural and urban tourism destinations are a popular battlefield where businesses strive to attract the attention of tourists. Some studies have investigated the perceptions of tourists on either the rural or the urban tourism destination. However, comparisons of these two destination types are scant. The current study attempts to empirically compare tourists' experiences of rural and urban tourism destinations in the Eastern Cape of South Africa. To achieve this purpose, five experience dimensions, namely education, aesthetics, entertainment, escape, and peace of mind (Pine \& Gilmore, 1998; Amoah et al., 2016) served as the basis of the study.

The results of the study confirm the generally positive experience of tourists for all five dimensions at both the rural and the urban destinations. The results also show significant differences for the escape $(\mathrm{p}=0.001)$ and peace of mind (0.001) dimensions. Hence, $\mathrm{H} 4$ and $\mathrm{H} 5$ were supported, while hypotheses H1, H2 and H3 were rejected. These findings are consistent with those by $\mathrm{Oh}$ et al. (2007) and Quadri-Felitti and Fiore (2012) that tourists' experiences of a destination will differ across destinations. The respondents indicated slightly higher levels of escape $(\mathrm{M}=3.55)$ in the rural tourism destinations than in the urban ones $(\mathrm{M}=3.28)$. This seems to suggest that rural tourism destinations provide more opportunities that allow tourists to been grossed and immersed in the experience to the extent of forgetting themselves or their daily routine activities. Rural tourists might also have experienced playing a different role or character at the destination which may not be the case with the urban tourism destinations. To attract more tourists to an urban tourism destination, it would be important to provide opportunities that would allow tourists to escape from their daily routine and view themselves as different human beings, for example, by incorporating cultural dances, cultural music displays, interaction with local people, informal dining with the locals and assorted meals into their destination's offerings. These can be offered at a minimal or no extra cost.

About the peace of mind dimension which encompasses safety, security, and privacy, it emerged that tourists who visited an urban tourism destination felt more secure and safe and that their privacy was respected $(M=3.51)$ than those who visited the rural tourism destinations $(M=3.22)$. To attract more tourists to rural tourism destinations such as Port St. Johns or Coffee Bay in the Eastern Cape of South Africa, it is important for the government, local communities, headmen, and other stakeholders to work together to eradicate crime and to assure tourists of their safety, security and privacy. This can be achieved through community education, and sharing information of the importance of tourism (e.g. employment, empowerment, 
development) in the area and the country at large. The government can also intensify police patrols at popular vantage areas where tourists frequently visit. Business owners of lodges, B\&Bs and restaurants, can also assist communities in various ways, for example through self-empowerment projects, private security patrols and other logistics, to help the police maintain law and order. It has been shown that in South Africa, support by residents such as night patrols, alerting the police of crime scenes, and collaborative effort with the security personnel's of the community is vital for the rural tourism development. It is therefore recommended that this effort should be encouraged and enforced by the local municipality with more dedication and provision of the necessary resources that can enhance its effectiveness.

Although no significant differences occurred in the other dimensions, their mean scores are worth noting. The mean score for aesthetics for both rural and urban destinations was higher than any of the other dimensions, suggesting that tourists were more positive about the aesthetics provisions such as attractive environment, a sense of harmony and a pleasant environment. These results corroborate the findings of Loureiro (2014) and Oh et al. (2007) that the aesthetic dimension is the most dominant dimension in shaping a tourist's overall experience. The mean score for aesthetics in an urban tourism destination $(\mathrm{M}=3.81)$ was higher than the mean score for aesthetics in a rural destination $(\mathrm{M}=3.72)$. To be competitive, it is recommended that rural tourism destinations would have to improve the scenery, cleanliness, attractiveness, and pleasantness of the physical environment. Examples of the latter might be the provision of comfortable chairs and functional equipment at the various accommodation options which match those of the urban destinations and maintaining regular cleanliness of the environment. The mean score for education associated with the rural tourism destinations was higher $(M=3.57)$ than the mean score of urban tourism destinations $(M=3.46)$. This might suggest that tourists were attracted to rural tourism destinations owing to opportunities to enhance their skills, acquire new knowledge, or learn more from the rural people. Thus the results are consistent with prior studies by Huang et al. (2016) and MacDonald and Jolliffe (2003) who found that education experience are distinct factors for attracting tourists to rural tourism destinations. From a managerial perspective, it is recommended that managers of urban tourism destinations provide opportunities that can assist tourists in enhancing their skills, learn new things or acquire more knowledge. The use of qualified and knowledgeable guided tours can enhance this dimension. A designated vantage area should be reserved for artistic and craft designs to provide tourist with an opportunity to learn basic art and craft designs from the experts. This can enhance the tourist's education experience. Attractive and well-resourced museums with ample art exhibitions and documented valuables (e.g. history) can also be offered to attract tourists. Displays of these items could be changed on a regular basis to encourage regular visits.

A slightly higher mean score for entertainment was recorded for the rural tourism destinations ( $M=3.59)$ when compared to the urban coastal destinations $(M=3.56)$. This lends support to the findings by MacDonald and Jolliffe (2003) that entertainment forms an important component of rural tourism experience. Thus, it is recommended that managers of urban tourism destinations could introduce more entertainment opportunities to attract more tourists who seek to be entertained. For example, incorporating and organising more authentic traditional cultural displays (e.g. songs, acts or dances), the introduction of street carnivals, competitions, international concerts, fashion events, hosting events that would bring local residents and tourists together for a collaborative sharing experience of culture and history and other entertainment facilities within various urban tourism destinations would attract more tourists.

Limitations and recommendations for further studies: As is evident in all other research, the current study has minor limitations which create avenues for future research. Firstly, the study was confined to four (two rural and two urban) tourism destinations in the Eastern Cape, South Africa and this limits the generalisability of the findings. Future research could extend the scope of the study sites to other provinces with the aim of generalising the findings. Secondly, five experience dimensions were selected as the basis of the investigation. Since several experience dimensions exist in the literature, future researchers should incorporate other relevant dimensions such as novelty, hedonics, and economic value (value for money) that may assist businesses and governments to better the experience of tourists at various tourism destinations. Finally, an empirical analysis that compares the satisfaction and behavioural intentions of tourists may be worth investigating. 
Acknowledgements: The financial support of the National Research Foundation (NRF) of South Africa towards this study is acknowledged. However, any opinions, findings, conclusions and recommendations are those of the authors. The funding institution does not accept any liability in regard thereto.

\section{References}

Achiam, M. (2016). The role of the imagination in museum visits. Nordisk Museologi, 1, 89-100.

Adhikari, A. \& Bhattacharya, S. (2016). Appraisal of literature on customer experience in tourism sector: A review and framework. Current Issues in Tourism, 19(4), 296-321.

Ali, F., Hussain, K. \& Ragavan, N. A. (2014). Memorable customer experience: Examining the effects of customer experience on memories and loyalty in Malaysian resort hotels. Procedia-Social and Behavioural Science,144, 273-279.

Amoah, F., Radder, L. \& van Eyk, M. (2016). Experience quality dimensions and customer perceptions: A case study of guesthouses in Ghana. African Journal of Hospitality, Tourism and Leisure, 5(4), 2016.

Amoah, F., Radder, L. \& van Eyk, M. (2017). Experience composite worth: A combination of experience quality and experience value. South African Business Review, 3, 292-310.

Andrew, D. P., Pedersen, P. M.,\& McEvoy, C. D. (2011). Research Methods and design in sports management. Champaign, USA: Human Kinetics.

Ashworth, G.\& Page, S. J. (2011). Urban tourism research: Recent progress and current paradoxes. Tourism Management, 32, 1-15.

Barbini, F. M.\& Presutti, M. (2014). Transforming a peripheral area in an emerging tourism destination. Tourism Geographies, 16(2), 190-206.

Beames, G. (2003). The rock, the reef and the grape: The challenges of developing wine tourism in regional Australia. Journal of Vacation Marketing, 9(3), 205-212.

Butler, G. (2017). Fostering community empowerment and capacity building through tourism: Perspectives from Dullstroom, South Africa. Journal of Tourism and Cultural Change, 15(3), 199-212.

Carlisle, S., Johansen, A.\& Kunc, M. (2016). Strategic foresight for (coastal) urban tourism market complexity: The case of Bournemouth. Tourism Management, 54, 81-95.

Cetin, G. \& Bilgihan, A. (2016). Components of cultural tourists' experiences in destinations. Current Issues in Tourism, 19(2), 137-154.

Cohen, E.\& Ben-Nun, L. (2009). The important dimensions of wine tourism experience from potential visitors' perception. Tourism and Hospitality Research, 9(1), 20-31.

Ferreira, H.\& Teixeira, A. A. (2013). Welcome to the experience economy: Assessing the influence of customer experience literature through bibliometric analysis. FEP working Papers. Retrieved from http://www.fep.up.pt/investigacao/workingpapers/wp481.pdf

Ferreira, S. L.\& Hunter, C. A. (2017). Wine tourism development in South Africa: A geographical analysis. Tourism Geographies, 19(5), 676-698.

George, R. (2017). Responsible tourism as a strategic marketing tool for improving the negative image of South Africa. Worldwide Hospitality and Tourism Themes, 9(5), 543-554.

Gravetter, F. J.\& Wallnau, L. B. (2013). Statistics for the behavioural sciences. Wadsworth: Cengage.

Hair, J. F., Black, W. C., Babin, B. J.\& Anderson, R. E. (2010). Multivariate data analysis (7 ed.). Upper Saddle River, NJ: Prentice Hall.

Holland, J., Burian, M.\& Dixey, L. (2003). Tourism in poor rural areas: Diversifying the product and expanding the benefits in rural Uganda and the Czeck Republic. PPT working paper, No. 12. Retrieved from http://lib.icimod.org/record/11291

Houston, J. R. (2013). The economic value of beaches: A 2013 update. Shore and Beach, 81(1), 3-11.

Huang, W. J., Beeco, J. A., Hallo, J. C.\& Norman, W. C. (2016). Building attractions for rural tourism development. Journal of Sustainable Tourism, 24(10), 1387-1402.

Jurowski, C. (2009). An examination of the four realms of tourism experience theory. International CHRIE Conference - $\quad$ Refereed $\quad$ Track $23 . \quad$ Retrieved from http:scholarworks.umass.edu/refereed/Sessions/Wednesday/23

Kalbach, J. (2016). Mapping experiences: A complete guide to creating value through journeys, blueprints and diagrams. Sebastopol: O'Reilly.

Kirillova, K., Fu, X.\& Cai, L. (2014). What makes a destination beautiful? Dimensions of tourists aesthetic judgement. Tourism Management, 42, 282-293. 
Klaus, P.\& Maklan, S. (2013). Towards a better measure of customer experience. International Journal of Market Research, 55(2), 227-246.

Loureiro, S. M. (2014). The role of the rural tourism experience economy in place attachment and behavioural intentions. International Journal of Hospitality Management, 40, 1-9.

MacDonald, R.\& Jolliffe, L. (2003). Cultural rural toursim: Evidence from Canada. Annals of Tourism Research, 30(2), 307-322.

Mehmetoglu, M.\& Engen, M. (2011). Pine and Gilmore's concept of experience economy and its dimensions: An empirical examination in tourism. Journal of Quality Assurance in Hospitality and Tourism, 12, 237255.

Nunnally, J. C. (1978).Psychometric Theory. New York: McGraw-Hill.

Oh, H., Fiore, A. M.\& Jeoung, M. (2007). Measuring experience economy concepts: Tourism applications. Journal of Travel Research, 46, 119-132.

Pine, J. B.\& Gilmore, J. H. (1998). Welcome to the experience economy. Harvard Business Review, 76(4), 97103.

Pine, J. B.\& Gilmore, J. H. (1999). The experience economy: Work is a theatre and every business a stage. Boston: Harvard Business School Press.

Quadri-Felitti, D.\& Fiore, A. M. (2012). Experience economy constructs as a framework for understanding wine tourism. Journal of Vacation Marketing, 18(1), 3-15.

Roca, E., Villares, M.\& Ortego, M. I. (2009). Assessing public perceptions on beach quality according to beach users' profile: A case study in the Costa Brava (Spain). Tourism Management, 30(4), 598-607.

Rogerson, C. M. (2015). Tourism and regional development: The case of South Africa's distressed areas. Development Southern Africa, 32(3), 277-291.

Statista. (2017). Retrieved 11 17, 2017, from http://www.statista.com/topics/962/global-tourism/

Statistics South Africa. (2017). Retrieved 11 17, 2017, from http://www.statssa.gov.za/?p=4362

Sundbo, J.\& Darmer, P. (2008). Creating experiences in the experience economy. Cheltenham: Edward Elgar.

United Nations Conference on Trade and Development, 64th Session in Geneva (11-12 Sepetember 2017). (2017). $\quad$ Retrieved $11 \quad 22, \quad 2017, \quad$ from http://unctad.org/meetings/en/SessionalDocuments/tdb64d2_en.pdf

United Nations World Tourism Organisation. (2017). World Tourism Organisation UNWTO. Retrieved 11 17, 2017, from http://www2.unwto.org/content/why-tourism

United Nations World Tourism Organisation UNWTO. (2017, 11 17). United Nations World Tourism Organisation UNWTO. Retrieved from Why tourism?: http://www2.unwto.org/content/why-tourism

Viljeon, J.\& Tlabela, K. (2007). Rural tourism development in South Africa: Trends and Challenges. Cape Town: Human Sciences Research Council. 